\title{
How can traditional livelihoods find a place in contemporary conservation politics debates in India? Understanding community perspectives in Sundarban, West Bengal
}

\author{
Amrita Sen ${ }^{1}$ \\ Sarmistha Pattanaik \\ Indian Institute of Technology Bombay, India
}

\begin{abstract}
We document the economic and socio-cultural vulnerability of a forest-dependent community inhabiting the forest fringe island of Satjelia in the Indian Sundarban. Using simple artisanal methods, they have practiced traditional livelihoods like fishing and collecting wild honey from the forests for more than a century. Despite having established cultural integrity and traditional occupations, this group is not indigenous, and are therefore treated as 'others' and 'settlers.' An ethnographic study describes these various forms of livelihoods and the ways that threatens local subsistence. We also document the bureaucratic and hierarchical structure of protected area (PA) management, showing it has little or no accommodation of this community's local traditional knowledge. Finally, we ask whether there is any scope for integrating 'non-indigenous' environmental knowledge, for a more egalitarian transformation of socio ecological relations within these communities.
\end{abstract}

Keywords: Conservation, conflict, indigenous, political ecology, Sundarban, traditional livelihoods

\begin{abstract}
Résumé
Nous documentons la vulnérabilité économique et socioculturelle d'une communauté tributaire de la forêt qui habite l'île de la sylviculture de Satjeliadans le Sundarban indien. En utilisant des methods artisanales simples, ils ont pratiqué des moyens de subsistence traditionnels comme la pêche et la collecte de miels auvage des forêts, depuis plus d'un siècle. Bien qu'ils aient établi l'intégrité culturelle et les professions traditionnelles, ce groupe n'est pas indigène et sont donc traités comme «autres» et «colons». Une étude ethnographique décrit ces différentes formes de moyens de subsistence et les moyens qui menacent la subsistance locale. Nous documentons également la structure bureaucratique et hiérarchique de la gestion des aires protégées (AP), qui ne tient guère compte des connaissances traditionnelles locales de cette communauté. Enfin, nous demandons s'il y a lieu d'intégrer les connaissances environnementales «non autochtones», pour une transformation plus égalitaire des relations socio-écologiques au sein de cescommunautés.
\end{abstract}

Mots-clés: Conservation, conflits, indigènes, écologie politique, Sundarban, moyens de subsistence traditionnels

\section{Resumen}

Nosotros documentamos la vulnerabilidad económica y socio-cultural de una comunidad dependiente de un bosque que habita la isla límite de Satjelia en el Sundarban Indio. Con el uso de sencillos métodos artesanales, ellos practican desde hace más de un siglo, modos de subsistencia tradicionales tales como la pesca y la recolección de miel silvestre de los bosques. A pesar de haber establecido una integridad cultural y ocupaciones tradicionales, este grupo no es indígena y por lo tanto son considerados como “otros" y "colonos". Se trata de estudio etnográfico describe estos diversos modos de subsistencia y las maneras en que amenazan la subsistencia local. También documentamos la estructura burocrática y jerárquica del manejo de área protegida (PA), demostrando que tiene un poco o nada de reconciliación con el conocimiento tradicional local de esta comunidad. Finalmente, cuestionamos si existe alguna

\footnotetext{
${ }^{1}$ Amrita Sen, Senior Research Scholar (Sociology), Department of Humanities and Social Sciences, Indian Institute of Technology Bombay, India. Email: mailtoamrita29 "at" gmail.com. Dr. Sarmistha Pattanaik, Associate Professor (Sociology), Department of Humanities and Social Sciences, Indian Institute of Technology Bombay, India. Email: pattanaik.sarmistha78 "at" gmail.com. The authors gratefully acknowledge the anonymous reviewer as well as the editor, for their detailed and helpful comments on an earlier version of the manuscript. Any shortcomings are our own responsibility.
} 
intención de integrar conocimiento ambiental "no-indígena", para una transformación más igualitaria de las relaciones socio ecológicas dentro de estas comunidades.

Palabras clave: Conservación, conflicto, indígena, ecología política, Sundarban, modos de subsistencia tradicional

\section{Introduction}

The Bengali month of Kartik (late autumn) brought an implausible turn in the life of Paritosh. As a part of his routine, he summoned two other fellow neighbours from Mridhapara, his village and ventured onto a narrow creek of the Sajna River near Pirkhali in his small boat, searching for tigerprawn (Penaeus monodon) seeds in the brackish water. They caught juvenile prawn seeds until the weather turned gloomy and the murky waters made them rest their boat with a Hental tree (Phoenix paludosa) on the mudflats. Their work was done for the day, and they waited for morning. It was a full moon and the tidal surge had just started to recede, leaving behind corroded mudflats on the two sides. The moonlit forest above appeared creepy when three of them tied the boat to the shaft. As Paritosh made space in the front of the boat for a doze, a tigress grabbed him, missing its usual target (the neck of the prey) and dragged him away by the hands. While his other companions froze with terror, Paritosh fought back for over half an hour, managing to clutch its tongue and punch its cheek. His compatriots, terrified by the gaze of the tigress, managed only to turn the pulling net towards it, of which tigers are usually afraid. Maybe this 'archaic' pulling net saved his life that day, but that was the last fishing expedition for Paritosh. He is now jobless.

In this study, we explore an unprincipled exploitation of traditional livelihoods by conservation organizations and the state in India, which portray forest-dependent people as potential adversaries. In doing so, we adopt an approach based on political ecology. 'Politics' in political ecology, as Bryant (1998:80) points out, is the attempt to understand the ways in which human-environment interaction explains environmental degradation. Political ecology is a way of thinking about the environment which postulates that the kinds of access and use of ecological resources are marked by inequality, power relations and distribution conflicts (Guha and Martinez-Alier 1997:23-45; Harrison and Mdee 2017). By conceptualizing an image of nature as intrinsically related to human lives, scholarship combines the issue of conservation with a plea for social justice (Baviskar 1995; Cronon 1995; Adams and Hutton 2007; Forsyth 2008; Robbins 2012). Political ecology interrogates the kinds of political actions and social movements that emanate from ecological distribution conflicts. It engages with the "agency of idea and actions of social, economic and discursive power" in addressing the relationship between nature and society (Kull, Sartre and Larranaga 2015: 123). Political ecology extends 'cultural ecology', which dwells on traditional ecological practices (Forsyth 2003: 8). Building on this framework, this article examines the economic and socio-cultural vulnerability of a 'non-indigenous' forest-dependent community inhabiting the Indian Sundarban, positioning them in relation to 'nature.' Drawing on ethnographic fieldwork on the island of Satjelia in Gosaba block, in the district of South 24 Parganas in West Bengal (see Figure 1), we describe, using informants' own words, the methods of fishing and wild honey collection as practiced by forest-dependent communities. The use of political ecology in the context of the present study is significant, since our empirical observations establish the extent of state interventions in legitimizing 'authentic' forest rights, a process implicit in the method of conservation (Baviskar 1995:30; Karthik and Menon 2016).

According to Jalais (2004: 201), "environmental plans for the Sundarbans have been dominated by discourses dictated in the name of eco-science", that never took into account the plight of the inhabitants of the region. For instance, tiger attacks on those trying to eke out livelihoods from the forests of Sundarban, as the aforementioned vignette showed, are commonplace. Yet, there is a growing indifference among state officials towards such attacks and towards traditional livelihoods in general. In this context, we pose three questions. Firstly, what is the difference between 'indigenous people' and 'other' marginalized forest-dependent people, in terms of their collective rights, cultural heritage and livelihood claims? Secondly, how are traditional conservation norms articulated within the realm of the 'non indigenous'? Thirdly, how do the forest department's restrictions and coercions marginalize these 'non indigenous' forest-dependent communities culturally, politically and economically? 
Our questions have a particular importance because in the Sundarban Biosphere Reserve (SBR) ${ }^{2}$, the use of the word 'indigenous' is problematic due to an influx of migrants. Since the colonial period, there was tribal migration from the adjoining states of Bihar, Jharkhand and Odisha, people brought as indentured labourers by the British administrators to reclaim the forests of Sundarban (Chakrabarti 2009).After India's independence from Britain in 1947, rural people from East Midnapore and Bangladesh migrated to the region. Béteille (1998: 190) mentions that "the idea of indigenous people must have some basis in the territory inhabited by them in the past and the present." Having said this, he asserts that the term 'indigenous' symbolizes a homogenous identity, necessarily based on associations with a particular settlement since the past. Subsequent generations of a community coming and settling in other dispersed locations from their natives are 'settlers'; not 'indigenous' (ibid). But formal definitions of indigeneity may be at odds with the self-identity of a community and their history of occupancy. According to Gurr (2000), indigenous people are merely those who are the descendants of the earlier inhabitants of a region, living in conformity with traditional social, economic and cultural practices that are sharply distinct from those of dominant groups. Wilmer (1993) defines indigenous people as those with tradition based cultures, who were politically autonomous before colonization and who continue to struggle for the preservation of their cultural identity, economic self-reliance and political independence by resisting the assimilationist policies of the nation state. Other studies have focused on the uncertainty associated with "cultural authenticity" in defining indigeneity, since in many cases it is "articulated" and "claimed" through political strategies (Chhotray 2016:5). Irrespective of a "natural" indigeneity, different communities contest state power by the invocation of indigeneity, "to roll back state's territorial, social and political control over the countryside"(Li 2000:156). As pointed out by Gupta (1998:18), "...the effectiveness of indigenous identity depends on its recognition by hegemonic discourses of imperialist nostalgia, where poor and marginal people were romanticised at the same time that their life is destroyed."

In Sundarban, cultural identity is not based on an ascribed status like caste or class, or on venerable autonomy, but on traditional livelihood practices and a way of legitimating those livelihoods based on customary rights. On the islands where we conducted our fieldwork, rights and practices determine local identity. We depict how the people organize themselves to preserve nature, and practice livelihoods in an ecologically fragile landscape. We argue that 'non indigenous' economic and social contexts exist, as in the case of Sundarban, where communities adapt lifeways and practices to seek the cooperation of nature in sustaining themselves as well as natural resources.

\section{The relevance of 'indigenous' in the politics of conservation and the context in Sundarban}

According to the United Nations (UN), indigenous communities practice unique traditions, retain social, cultural, economic and political characteristics, and are distinct from those of the dominant societies in which they live. Gadgil, Berkes and Folke (1993:151) pointed out that "indigenous knowledge is defined as a cumulative body of knowledge and beliefs handed down through generations by cultural transmission about the relationship of living beings (including humans) with one another and with their environment." Traditional ecological knowledge may be considered as a subset of indigenous knowledge, referring to the traditional relationship of the communities with nature, inherited and sustained culturally through generations by involving ritualistic practices of reverence (Dudgeon and Berkes 2003:76). Political ecologists commonly apply the term 'indigenous people' to communities who oppose their disenfranchisement from traditional resource claims, through political actions and movements against the state (Adams and Hutton 2007; Peluso 1993). Greenough (2001: 142) traced the intimate dependence of indigenous people on the gifts of nature, and their material efforts to avoid market intrusion and technical innovations as well as their respect for, and traditional bonds with nature. For indigenous people, their territory is their cultural identity and includes forests, rivers and earth.

The Government of West Bengal, however, represents the inhabitants of Sundarban as 'nonindigenous', since they are not 'native' but migrant settlers from adjoining regions. Descendants of migrants have also lost the entitlement to be 'indigenous', despite their abject socio-economic conditions (Béteille 1998: 190) and their cultural associations with the forest. The state resorts to an "indigenistregionalist" version of environmentalism, that mediates against the forest rights of the migrants, since

\footnotetext{
${ }^{2}$ The Indian part of the Sundarban, including the forested and the inhabited area, is collectively known as SBR. In our article we refer throughout to the Indian Sundarban unless mentioned otherwise.
} 
they do not constitute an "authentic local" with "legitimate" forest rights (Chhotray 2016: 7). In the village where our study was conducted, inhabitants belong to the Indian categories of Scheduled Castes (SCs), Scheduled Tribes (STs) and Other Backward Castes (OBCs). ${ }^{3}$ While the SCs migrated from Bangladesh, the STs migrated from places like Jharkhand, Bihar and Odisha to reclaim forest lands and open them for settlement. OBCs migrated from the district of Midnapore in West Bengal. Although all three categories are migrants, many SCs have traditional associations with forest based occupations like fishing and honey collection, inherited from their forefathers in Bangladesh. However, for the STs and the OBCs, ecological knowledge is not inherited but mostly 'locality-specific', learnt from their experiences and growing associations with the forest after they migrated. Close proximity of the three categories in the region points towards a kind of assimilation of cultures and practices and mutual influence. Collectively known as 'forest workers', these forest-dependent communities in Sundarban exhibit established norms of forest usage and sacralised practices of reverence towards forest wildlife and deities (Hunter 1875; Chatterjee Sarkar 2010; Jalais 2010), an essential qualification for being 'indigenous.' Such reverence associated with forests in Sundarban can be traced back as early as the Mughal Empire period, when professional woodcutters and fishermen entered the realm of the forest only after worshipping the sylvan deity presiding over that particular tract (Eaton 1990:9). If 'indigenous' is an imposed category to recognize traditional rights, can political ecology expose the customary rights and the dilemmas of a category of forest-dependents that claim socio-economic and cultural similarities with recognized 'indigenous communities'?

Indigenous communities are more widely represented in academic scholarship. According to Corntassel (2003: 76), the dilemma over "who is indigenous" has become increasingly politicized as indigenous people have attained distinct legal standing under international laws and conventions. The International Labour Organization's (ILO) Convention of 1989 (No. 169) allocates rights to development, customary practices, lands and territories. ${ }^{4}$ Protection of indigenous cultural heritage and traditional knowledge, including knowledge of ecological resources and rights to land are recognized under Article 31 of the UN 'Declaration on the Rights of Indigenous People', 2007. Despite legal safeguards, indigenous people have suffered dispossession from their lands, territories and resources owing to the conservation agendas present in forest tracts (Baviskar 1997; Capistrano 2010; Gadgil and Guha 1995; Shahabuddin and Rangarajan 2007). In modern times the exclusionary policies of conservation have increasingly acquired a sharp ecological edge, being played out against the backdrop of resource scarcities (Gadgil and Guha 1992; 1994: 118). The politics of state control over conserving ecological resources is acted out through 'legitimate' violence over marginalized groups (Peluso 1993: 199; Sen and Pattanaik 2015). For instance, the dispossession of the indigenous communities like the Masai, Kamba and Orma of Kenya from their land and livelihood activities was prompted by the alliance between international conservation agencies and the Kenyan state, prioritizing wildlife protection (Peluso 1993: 202). Rangeland degradation of the Qinghai-Tibetan plateau in China has been attributed to livestock grazing activities by the pastoral Tibetans and Mongolians, without any systematic surveys conducted by the government (Harris 2010). Escobar (1998) reflects on the social movements of the black communities in the Pacific rainforest region of Colombia (who, although settlers, now have a special status and sovereignty over territories), which are focused on maintaining traditional ecological associations and livelihood activities.

Indigenous livelihoods and knowledge systems have proven their worth for conservation. Forest islands in the Amazon Basin called apete by the Kayapo Indians of Brazil create an architectural zone of medicinal species, palms and vines which produce drinking water. Many of the ancient fish rearing systems of China, Hawaii, Indonesia and elsewhere make use of a mix of species taking advantage of the ecological characteristics of each, and make full use of wastes, recycled to provide food (Gadgil, Berkes and Folke 1993: 155). For indigenous communities, most knowledge about the environment is ingrained in a set of material and ideological practices (Baviskar 2000). Alfred and Wilmer (1997: 27)

\footnotetext{
${ }^{3}$ In the four tier Indian caste system, the SCs are people who occupy the lowest tiers of the caste hierarchy, and were historically regarded as untouchables and profane by the upper castes. Due to their social disadvantage, they are now entitled to certain privileges by the government, the most important of which being the reservation of employment opportunities. According to Article 366 of the Constitution of India, the STs are such tribes or tribal communities, or parts of or groups within such tribal communities, which exhibit 'primitive' traits, distinct culture, geographical isolation, shyness towards contact and 'backwardness.' OBCs are regarded as the 'socially and educationally backward classes' by the Government of India. Their economic position is no better than the SCs and STs.

${ }^{4}$ See 'Indigenous Peoples and United Nations Human Rights System' (2013).
} 
argued 'indigenous' identities are linked to tradition-based cultures, with political autonomy prior to any colonization, cultural integrity, economic self-reliance and political independence. But what of the nonindigenous communities we studied, also living close to the forest? We argue that adopting pre-defined categories like 'indigenous', obscures many others. Also, overt claims to cultural integrity by indigenous people can marginalize other poorer communities, who cannot claim indigeneity (Chhotray 2016:6). Through our documentation of the traditional livelihoods in Satjelia, we portray that the established definitional standards of 'indigenous' identification might exclude 'other' marginalized forest-dependent communities from their rights to livelihood, their ideas of community building and their selfidentification and belief systems.

\section{The study area and methods}

The Sundarban is the largest mangrove forest in the world, encompassing an area of 25,500 $\mathrm{km}^{2}$, of which 9,630 $\mathrm{km}^{2}$ falls within India and the rest in Bangladesh. SBR, as the region is known in India, is partly inhabited $\left(5,367 \mathrm{~km}^{2}\right)$ and partly forested $\left(4,263 \mathrm{~km}^{2}\right)$. The inhabited area, or the transition zone of SBR, falls outside the forest area and is divided within the two districts of North and South 24 Parganas in West Bengal. Sundarban forest is the largest remaining tract of the Royal Bengal Tiger (Panthera tigirs), a predator who occupies an integral core of the terrestrial food-chain and is also known for its valour in man-eating. The eminence of the tiger coupled with a range of exotic mangrove species and aquatic resources have meant the SBR forests acquired Tiger Reserve status in 1973, became a National Park in 1984 and a Critical Tiger Habitat in 2007. UNESCO recognized the forest as a World Heritage Site in 1987.

The study draws from ethnographic fieldwork carried out in Emilibari village in 2015 and 2016. Situated in the island of Satjelia in Gosaba block of South 24 Parganas district, Emilibari is a forest fringe village sharing close proximity with the Sundarban Tiger Reserve (STR) ${ }^{5}$ and has 2,300 people in 356 households. The three categories of people in the village, as introduced in the previous section, are the SCs, STs and the OBCs. The southernmost islands like Satjelia are part of the active delta ${ }^{6}$, and constitute an unstable land surface since they are interspersed by small rivulets and are subjected to regular tidal swells, erosion and intrusion of saline water. As agriculture is erratic and unpredictable due to salinity, people in Emilbari mainly rely on forest-based livelihoods. Collectively known as 'forest workers', these people constitute a class of marginalized landless people, entirely dependent on the forest resources to subsist, as well as others who depend on forest resources in varying degree to supplement their income. ${ }^{7}$ Figure 1 is a map of the Gosaba block, indicating Emilibari village.

Data for our study was collected through 75 household interviews with the forest workers, dividing the sample into 12 ST and 63 SC households. Some 28 SC households were descendants of traditional fishing communities in Bangladesh. Snowball sampling was used to identify respondents. We complemented the interviews with informal and focused group discussions, since we felt that formal interview schedules would elicit poor response rates and reduce the chances of building a rapport with the respondents. All the households interviewed depend on the forests for livelihood, without supplementary income, and were mostly landless. The two foremost occupations were fishing (prawn seed collection, fish collection and crab collection) and honey collection. We only interviewed artisanal fishermen who practice inland fishing in the creeks and estuarine rivers with handmade nets and human driven wooden boats. We also consulted international NGOs like the World Wide Fund for Nature (WWF) and local NGOs like Direct Initiative for Social and Health Actions (DISHA) and the South Asian Forum for Environment (SAFE). There were discussions with local Fishermen's Unions including the Dakshinbanga Matsyaibi Forum (DMF) and Sundarban Matsyajibi Joutha Sangram Committee (SMJSC).

\footnotetext{
${ }^{5}$ STR falls within the forest area of SBR and measures $2,584.89 \mathrm{~km}^{2}$.

${ }^{6}$ There is a difference between 'active delta' and 'stable delta' in the Indian Sundarban. By stable delta we mean the islands which are situated upstream and are less exposed to the tidal currents of the rivers. They are therefore much more developed, are near to the cities and have low risks of river erosion. Active deltas on the other hand are the islands located downstream, closer to the forests and the mouth of the river. Tidal currents are always inundating them and they are under the constant risk of building and rebuilding by the tides (Jalais 2010).

${ }^{7}$ The forest based livelihoods which are commonly practiced by the forest workers in Emilibari includes forest fishing for fish, crab and prawn seed collection, honey and bee-wax collection.
} 


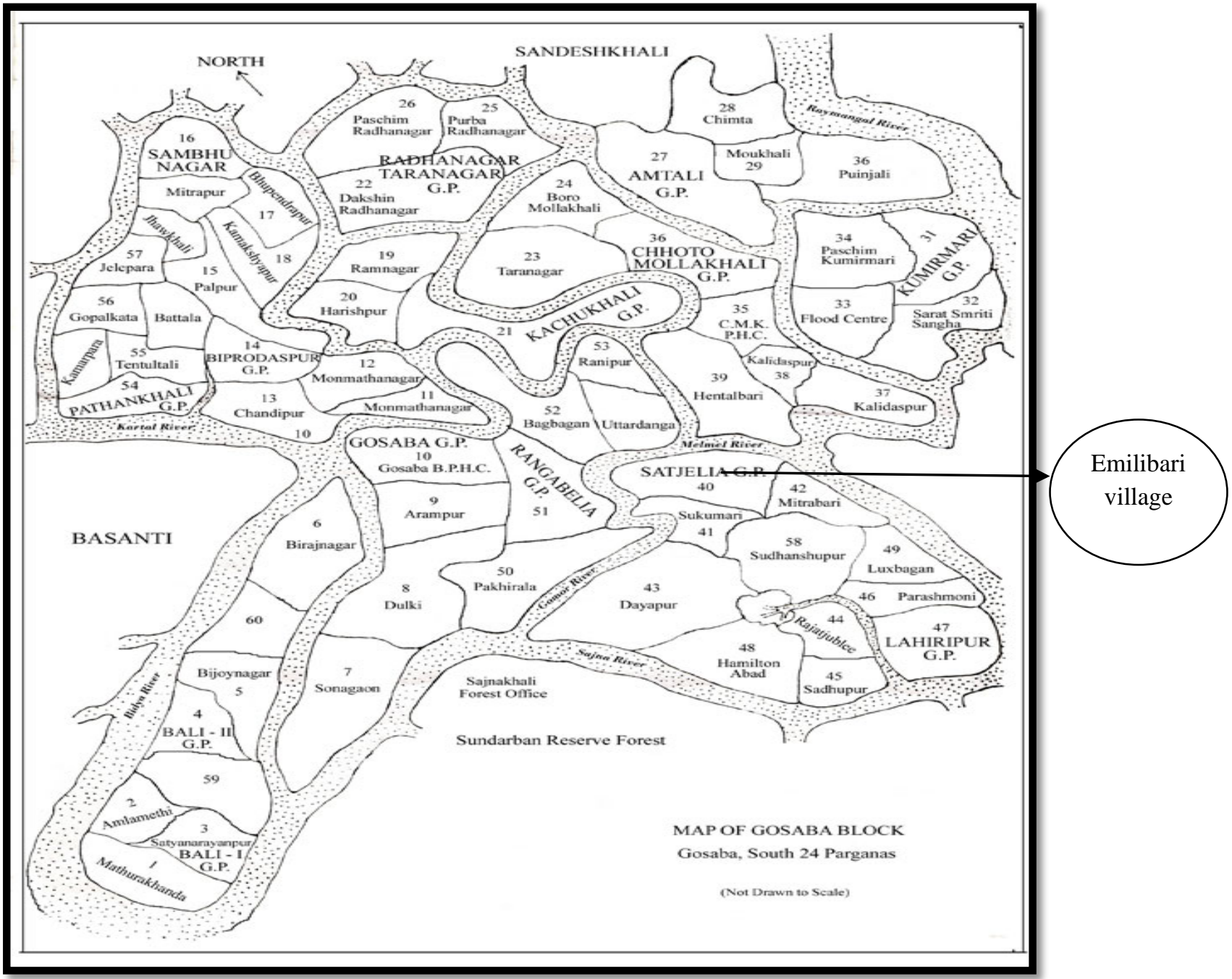

Figure 1: Map of the Gosaba block and the location of Emilibari. Source: Office of theSTR.

\section{Forest fishing for subsistence: traditional practices and dilemmas}

According to the Central Marine Fisheries Research Institute the 13inhabited blocks of SBR within the district of South 24 Parganas, have a total marine fisher population of 197,781 in 40,684 households, spread over 68 village councils (gram panchayats ${ }^{8}$ ) (CMFRI 2010). According to other estimates, 35,330 people work in the forest of SBR annually, of which 4,580 collect timber and firewood, 24,900 are fishermen, 1,350 collect honey and 4,500 are involved in other activities (DISHA 2009:13). However in the village where we conducted our study, there are no marine fishers. People fish in the creeks and estuaries interspersed within the forest areas and are thus referred to as 'forest fishers.'

After the formation of STR in 1973, Boat Licence Certificates (BLCs ${ }^{9}$ ) were issued to each boat owner who was a fisherman. Presently, the total number of BLC is 923 under the STR area and 3,750

\footnotetext{
${ }^{8}$ Gram panchayats in India are the local self-governance institutions in individual villages. Their members are elected by the adult members of a village, for a period of five years.

${ }^{9}$ BLC implies a registration certificate to be issued to all registered fishers by the government to carry out fishing within the permitted water bodies inside SBR. BLCs can inherited through ancestral lineage but are nontransferable. However they can be rented to others.
} 
under the reserved forest area, outside the STR. However, only 650 BLCs are active now in STR, far less than is needed, while the rest are dysfunctional. A fisherman with a BLC has to pay Rs 40 (US\$ 0.62) as a pass to the STR forest office to fish in the admissible areas - catching crabs costs Rs 10 (US\$ 0.15) per gear per trip. Two things need to be clarified regarding the issue and ownership of BLCs. Firstly, these BLCs have been around a long time and are now mainly owned by rich agriculturalists and middlemen, whose ancestors were fishers. ${ }^{10}$ The middlemen buy fish from the fishermen when they return from fishing. These middlemen, known as aratdaars or khotidaars, lend money to the fishermen and provide them with boats and nets on the condition that the fish caught has to be sold to them at concessional rates. ${ }^{11}$ The poor fishermen, who are in present need of the BLCs, thus have to rent them from the aratdaars at Rs 30,000- 45,000 (around US\$698) for a period of nine months to one year, during the fishing season. This rent applies to the BLCs within STR, while for the BLCs outside STR; the rent is a little lower, around Rs 10,000-15,000 (US\$233). Secondly, considering the growing number of forest fishers over the years, no fresh BLCs have been issued by the Forest Department after the initial allocation of 923 around 44 years back. As a result of this, most of the fishermen fish without a licence.

Gopalkrishna Haldar, a fisherman and a resident of Jahar Colony in Lahiripur, told us that the charge for renewing the licence per year from the Forest Department office amounts to Rs 500 (US\$ 7.76) presently, while the renting of a BLC from aratdaars costs Rs 45,000 (US\$698) a year (in 2016). Thus if a boat, which usually consists of three people while going for crab collection catches Rs 100,000 (US\$1,553) per season (November to March), the amount that goes on rent is Rs 45,000 (US\$698). Rs 500 (US\$7.76) has to be paid as BLC renewal charges from the Forest Department. The remaining Rs 54,500 (US\$846) is divided between the three people on the boat as the income from the season - Rs 18,000 (US\$279) to sustain a family. But the owner of the boat receives an amount higher than the other two.

With the extension of the core forest area of STR from $1,330 \mathrm{~km}^{2}$ to $1,700 \mathrm{~km}^{2}$ in 2007 , following its declaration as Critical Tiger Habitat, the villagers in Emilibari say they have been affected. The areas where fishing is permitted within the buffer zones $\left(522.85 \mathrm{~km}^{2}\right)$ are congested and overfished. The fishermen have to enter the core areas secretly, risking a fine of Rs 500 (US\$7.76) for the first offence, Rs 1000 (US\$15.52) for the second and Rs 1100 (US\$17.08) for the third if caught by a forest guard patrol boat. They have their BLC, boat and fishing gears confiscated if they are caught a fourth time. In this event, the patrolling boat usually transports them back to their village and leaves with the confiscated belongings. To release the licence and fishing equipment from the forest guards, fishermen travel long distances to the head office of the Forest Department and pay a ransom as penalty. Transportation costs for a fisherman for travelling to and fro to release the pass from a forest office costs Rs 200 (US\$3.12), plus the fine.

The BLC mentions the name and address of the boat owner and the other fishermen (usually three) on board, linked to Janata insurance ${ }^{12}$, the number and description of fishing and other equipment, and the amount of firewood carried for cooking purposes in their boats. If a fishing boat takes a simpler route to reach a permitted area of fishing quickly, it has to cross the wildlife sanctuary which falls under the core conservation area (Chacraverti 2014: 64). However, the Forest Department does not allow passage through the core (ibid). All of our respondents in Emilibari reported verbal abuse when crossing the core conservation area and some reported physical abuse. The fishermen are often confronted by the forest guards even if they are found in the surrounding buffer zone, simply because the guards presume that these fishermen are retreating from restricted or core areas. Their boats, BLCs, fish catch and fishing nets are often confiscated and heavy fines are imposed.

Harvesting crabs, fishing, and prawn seed collection are the three main activities along the forested creeks and rivers of STR. These involve three discrete locations. While catching crab, forest fishers enter the narrowest creeks within the forests which are inundated during high tides and dry during low tides. Fishing occurs in creeks but mainly along main river bodies, apart from a few fish species found in creeks. Prawn seed can be caught along river banks with pulling nets. In many cases,

\footnotetext{
${ }^{10}$ These people have improved their economic status over the years and have given up on fishing.

${ }^{11}$ In Sundarban, arat or khoti is a trading camp that governs the fish trade. It is usually located in the villages inhabited by the fishers along the riverbank. Aratdaars manage or own these fishing camps and are economically wealthier than the forest fishers.

12 Janata Personal Accident Insurance is available from National Insurance Companies to people going for fishing and honey collection below 60 years of age. It costs Rs 100 (US\$1.55) per year (Ghosh 2014).
} 
the fishermen have to travel at least a day to reach a location, and their trips last 7 to 14 days. Prawn seeds, on the other hand, can be caught while pulling the fishing nets along the bank of the river or froma boat.

Fish

According to the respondents from Emilibari, fishing occurs from June to the end of October and there are at least six methods used. Wooden rowing boats carry five to six people. Fishermen look for a section of collapsed riverbank. They know that species including Bhetki (Lates calcarifer) and Tengra (Pimelodus cenia) will be abundant. They encircle this breached area with a drag shore seine net which has wooden sticks attached to both ends and middle. Two people take the head of the net and move into the water towards the bank and two more do the same in the middle. The remaining two exit from the other end of the boat, encircling the breached bank. This system is called bait. Then, after some time, using sticks, the fishermen dig into the mud to make it easier for the fish to enter the nets with the water current. Gradually, the net is lifted up and emptied into the boat. It is risky because many times, it attracts crocodiles. In that case, the net has to be released from one side to avoid tearing, or a crocodile attack.

The second technique involves the use of a gillnet, locally known as galsha, which six to eight fishermen carry in a bigger boat. This nylon net is almost 25 feet $(7.6 \mathrm{~m})$ in width with a mesh size of $13-16 \mathrm{~cm}$ to catch bigger fish. Using the same process as above, one end is fixed by a stick at a riverbank and the other is anchored some distance away. White buoys mark it and keep it afloat. These nets are usually fixed at night during the ebb tide. After the high tide the nets are withdrawn so that the fish remains caught by the ebb. Ten to fifteen such nets are placed across the rivers. The fish are Dyatne (common carp), Parse (Liza Parsia), Topse (Polynemus paradiseus) and Bhetki.

The third system uses a small dinghy boat with two wooden poles attached on either side to which the fishing net is attached. These are floated for a distance of about 200-300 feet (61-91m) and have a mesh size of around $75 \mathrm{~mm}$. There are three crew members, with one rowing. The fishing net is spread along the belly of the river and pulled by hand from each banks. The fish caught include Parshe, Pyra (Scatophagus argus) and Chingri (shrimp). The fishing nets used are called fixed bagnet or beoundi, locally.

The fourth technique involves the use of hook and line or kata don, locally. Four to five lines have fishing hooks like elongated knives attached along them (called borshi). A little snail or small trout are attached as bait. Lines are tied to a wooden log on one side of the bank and stretch out downstream at a small distance from the edge and are reattached at the other end. After an hour or two, the fishermen come looking for fish along the thread. This type of fishing is practiced in very narrow creeks. The fish caught by this method include Tengra, Bhetki, Baan (․nguilla bengalensis) and Kajli (Tenualosa Toli).

The fifth system is comparatively common - the use of a spreading net or khyapla jal which is thrown into the water standing at the bank of the river. This net is quite heavy and is lined with lead weights, which imprisons the fish. It is thrown into the river by an individual, standing at the riverbank. It does not need a group.

The last system of fishing is practiced in a very narrow creek just when the water starts receding from the forest land. These creeks are almost devoid of water during the ebb tide and have dense mangrove forests on two sides; an ideal home for the tiger. The nets used are known as Khalpata or channel seine nets, usually hundred to two hundred feet long and are fixed across the mouth of the creek. One end of the net is placed by a rope tied to the trunk of a tree during low tide, so it can be pulled during high tides. These nets are fully immersed during high tide. When the water completely recedes, the fish caught within them can't go back. The mouth of the net has to be shut during the high tide to prevent the fish from coming out. The fisherman has to capture the few fish that are still caught in the muddy water, after washing them in the river water. At this time, they are vulnerable to tiger attacks as they are working in the dried up creeks. Parshe and Baan are the popular varieties of fish caught by this technique, and shrimp (Chingri). Another kind of net, called a fixed shore net or Charpata is also used. This is almost 100 metres in length with a mesh size of $20 \mathrm{~mm}$ and is tied with a bamboo pole at regular intervals during the ebb tide. As the water rises, the fishermen pull up the net gradually and the fish remains caught, coming with the inflow of water and then getting stuck. Tiger attacks are also possible as the operator is bending down to push the water towards the net. The two 
sides of the creeks are high after the water recedes, from where it is easier for the tiger to spot the man standing on the land below, engrossed in catching fish, thus attacking him from behind.

\section{Crabs}

The second form of forest fishing involves the harvesting of crabs (Brachyura) in the narrowest creeks of the forest. The crab harvesting season, as the collectors say, extends from September to March, although the best catch is expected from November to March. For catching crabs, the STR forest office issues a permit for four people, per boat. But usually three occupy one boat since the income earned is very low and is not sufficient to support four families, after paying for the licence and the permit. Crab collection follows a definite lunar cycle i.e., the period of fifteen days following the new moon and the full moon, known as Suklapaksha and Krishnapaksha respectively. The day of full moon is locally known as purnima while the day of new moon is called amabasya. The duration of the tides and their timings during crab fishing season controls the movement of fishers. Suklapaksha and Krishnapaksha are divided into short spans. The period of five days from the start of suklapaksha and krishnapaksha is the time when the tide is strongest and the catch of crabs is highest. During this period, the river creeks are inundated. Most of the crab collectors venture out for collection during this time. For four to five days after that the tide is weaker, and the catch is less. During the preceding few days of full moon or new moon, the tide is again very strong and crabs are abundant. The crab collectors usually start on the tenth day of the fifteen day cycle, i.e. five days before amabasya or purnima and come back on the third or fourth day of the cycle. Each fifteen day cycle before full moon and new moon is locally known as gon. The crab fishers never start their first journey of the collection season on Saturdays and Tuesdays or on the day of full moon or new moon. For the entire period of collection inside the forest, which extends for around seven days, the fishermen carry with them rice, groceries, drinking water and vegetables for their daily meals on the boat. The essential stock for a crew of three fishers includes cooking utensils, $1 \mathrm{~kg}$ edible oil, $15 \mathrm{~kg}$ of rice, $1 \mathrm{~kg}$ of potatoes, spices $(500 \mathrm{~g})$, pulses $(500 \mathrm{~g})$, kerosene and 616 litre barrels of drinking water. They also have to carry 800-1,000 kg of ice to preserve the crab, placed in a wooden cold store (Ghosh 2014:137).

The procedure of crab harvesting involves tying tiny trout called chuno to long threads of plastic or nylon (don). They are dried beforehand, so that the crab cannot devour one easily. The line spreads linearly for about $150 \mathrm{~m}$, immersed at low tide along very narrow creeks where tiger attacks are possible, so narrow that in many cases the vegetation has to be cut back as they move along and drop the line. Since the creeks are narrow, the banks on the two sides make it easier for a tiger to jump onto the boat. The foliage of Hental or a Garjan (Rhizophora mucronata) tree is so dense that visibility is too poor to spot a camouflaged tiger. One person stays at the back of the boat, one at the middle and one at the front. The person at the middle drops the line while the other two steer. They then anchor and wait at the end of the creek for about fifteen to twenty minutes for the crabs to be hooked, and then withdraw the line. They use a spoon like vessel called jalti, to fetch the crab from the fishing line. Another method involves the use of an iron rod (sheek), with a bent mouth to dig the holes where the crabs are found. An experienced crab collector usually knows the holes where big crabs reside. Larger crabs have greater market value. The crab collectors estimate that if the catch is good, around 100 crabs can be caught on a $15 \mathrm{mlong}$ line. The crabs are sold to the aratdaars owning the BLC, to whom they are contracted. Of course the aratdaar buys cheap and sells at a much higher price. While the crabs used to be graded (female, and weighing 250 gm or more) by the aradataar before paying the fishermen, presently the fishermen sell any size at Rs 24,000 (US\$375) or Rs 25,000 (US\$389) per quintal (100 $\mathrm{kg}$ ). Selling crabs in bulk does allow those weighing less than $100 \mathrm{gm}$ to be sold, which encourages overfishing. Aratdaars sell the crabs to the fish market in the cities through the traders (paikars ${ }^{13}$ ), for a a higher price. Female egg laden crabs are sold separately and are the most expensive (Rs 500/US\$7.80 for $180 \mathrm{gm}$ ). Those without eggs are Rs 300(US\$4.68) per 180 gm or more. Male crabs are cheaper, costing around Rs 200 (US\$3.12) for 200gms, Rs 300 (US\$4.68) for 300 grams. Aratdaars sell these crabs in Canning from where paikars auction them and send them to Kolkata, where they are packaged and mostly exported to Taiwan, Shanghai, Bangkok and other destinations.

\footnotetext{
${ }^{13}$ According to Mukhopadhyay (2016: xii), paikars are traders who buy fish from the aratdaars and sell them to business people in Kolkata.
} 


\section{Prawn seed}

Prawn seed collection is the third major fishing activity. We came across families where almost all members of a family pull nets at the bank of a river. There are two main techniques.

The first method involves the use of a pulling net, commonly known as tanajal which is attached to a rope by its end. This is $0.9-1.2 \mathrm{~m}$ wide and $1.5-1.8 \mathrm{~m}$ long and looks like a mosquito net. It is mainly used by women in the evening and early morning during high tide, when they wade through chest deep water of the river along the banks in the villages, pulling the nets. Pulling nets are also used along the banks of the river close to the forest, again susceptible to tiger attacks.

The second method involves the use of a net which is dipped into the water from a boat in midriver, although poor families do not possess boats. This shoot net is triangular in shape and is tied to wooden poles attached to the boat. One end of the pole is fixed in the mud bank while the other end is tied to a nylon rope. The collected prawn seeds are kept in a white aluminium pot to segregate them from fish or bugs. Prawn seeds are in many cases caught by people who are not fishermen by profession. It is a very local occupation which might earn a family a day's expenses. Since people go chest deep into water to spread the net, crocodile attacks are common, along with tiger attacks, as previously mentioned.

After collection, prawn seeds are counted and segregated carefully, which is a long process. Seeds are then sold off to aratdaars who come to each village in search of collectors. According to Jalais (2010), the price fetched by the prawn seed collectors from the aratdaars during the monsoon months goes as low as Rs50 (US\$0.78) for 1,000 seeds while during lean seasons of January and February, 1,000 seeds can fetch about Rs1,000(US\$15.55). The aratdaars deposit their purchases at their landing centres. Here the seedlings are kept to grow for two weeks and are then sold off to the prawn fisheries. However this entire process of collecting and selling of prawn seeds is conflictual in terms of price, quantity and cheating during the counting process (Jalais 2010).

Apart from the forest dwellers whose ancestors fished in Bangladesh, others have 'adapted' to forest fishing through experience and acquisition of skills over long periods. Knowledge about the tides and the moon during crab harvesting, the kinds of net required for different locations and fish species, and use of pull nets for prawn seeds are 'locality-specific' practices. They are acquired and adapted through growing association with the forest, after migrating to the island. Contrary to the culturally inherited ecological knowledge of indigenous communities, for the forest fishers in Sundarban, ecological knowledge is 'learned' to seek nature's cooperation in eking out a livelihood. Despite practicing traditional and sustainable fishing, analogous to indigenous methods of subsistence-based livelihoods, the Forest Department refuses to regard the forest fishers as indigenous. This "indigenist" assertion questions the "authenticity" of the forest fishers as they seek legitimacy for their livelihood claims (Chhotray 2016). Since state bodies are empowered to control and regulate natural resources, they consider enforcement or coercive conservation as the easiest way of establishing control over people and resources (Gadgil and Rao 1995; Peluso 1993: 201). In Sundarban, complexities in determining access and rights over resources are thus further acted out through social identity, since struggles over ascribed identity and meaning(indigenous, or migrant) influence resource allocation as much as struggles over surplus or labour (Bryant 1992:22). Ideas about cultural identity, rights and traditional practices are debilitating for the forest workers in Sundarban, since they lack cultural attachments to place.

\section{The practice of Mahal: wild honey collection in the Sundarban forest}

Honey collection makes a substantial contribution to rural livelihoods and Emilibari has a significant number of people who are honey collectors. The livelihood activities in Sundarban are not mutually exclusive, and driven by extreme poverty, residents fish as well as collecting honey. The entire honey collection cycle begins and ends at home, and is known as mahal. The STR issues passes/licences to at least 1,000 boats, each honey-collecting season. The season includes the two Bengali months of Boishakh and Joistho (April and May) for a period of fifteen days each. Some collectors noted that passes are sometimes issued for 21 days. Before venturing out the following day, a meeting is held by a team of honey collectors. This meeting is headed by the sajandar or the team head, 
who decides the place of visit and the plan. An entire boat with a crew of 7 to 8 collectors gets a licence for Rs 27 (US\$0.42). Honey collectors, known as mawaley, row to the forests from their villages, in groups of seven or nine boats.

While reaching a particular island, all but one of the team disembarks. The honey collectors go deep inside the forest where hardly any sunlight enters, even during daytime. The remaining person (bhorel) carries a loud whistle called singhe with him to help the others retrace their steps. Formal procedures are followed before entering the dense forest. Before entering a particular forest, a tiger charmer $^{14}$ (locally known as bawaley) touches the ground with his hands as a sign of praying to the forest deity Bonbibi ${ }^{15}$ to seek her blessings in protecting the group from any impending danger. Tiger charmers are believed to inherit mystical powers through these blessings, and they are always a member of a honey expedition. They can 'control the environment of the forest', including the movement of a tiger, shut its open mouth and predict areas in the forest where a tiger is present. If he senses any danger, he advises others to leave and search for honey elsewhere. Slang, prohibited words, and defecating are forbidden in the forest. Collectors dress only in a cloth from waist to knee and hold a stick on their right shoulder. They carry a steel vessel in which the honey is to be stored and a large knife with them to cut the hive. They can wear a rubber face mask on the rear of their head to confuse tigers and keep them away, but collectors rarely do so, believing it will enrage Bonbibi. On entering, the team disperses, horizontally at a distance of 20 hands from each other while moving in, in search of trees like Hental, Genwa (Exocoecaria agallocha), Khalsi (Aegiceras corniculatum), Garjan and Keora ( Sonneratia apetala). Since they remain dispersed from each other while searching for a hive, they communicate to the others through signs if they locate a honeycomb. All of them then gather under the tree bearing the honeycomb, to extract the honey (Figure 2).

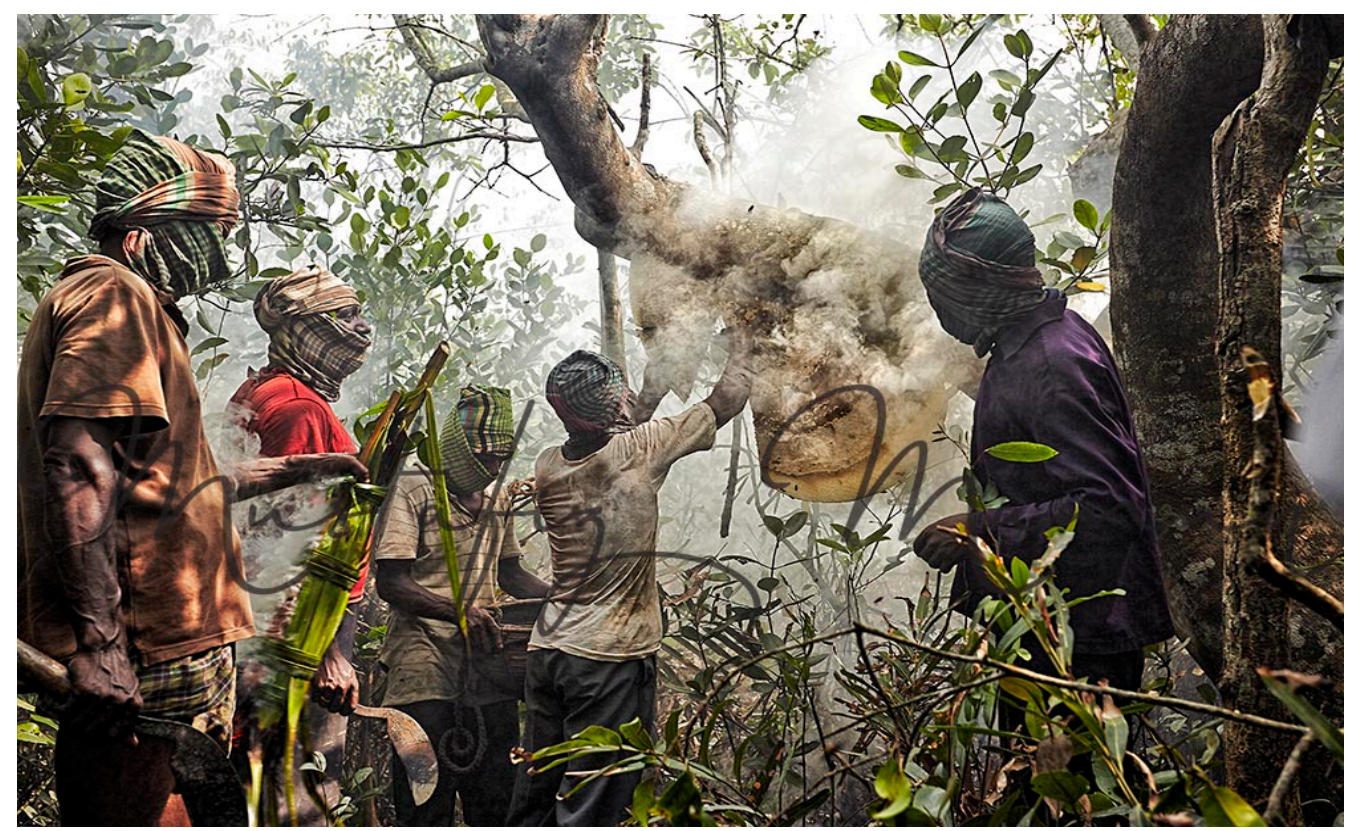

Figure 2: Wild honey collection from the forest. Source: Muhammad Mostafigur Rahman. $^{16}$

\footnotetext{
${ }^{14}$ The term 'tiger charmer' is taken from Jalais (2010).

${ }^{15}$ Bonbibi is a goddess who is widely worshipped in the Sundarban, especially by the fishermen and the honey collectors. She along with her brother, Shah Janguli is believed to protect the forest workers from the clairvoyant and the ominous tiger demon Dakshin Ray, who rules the forest and feeds on forest workers. Bonbibi and Shah Janguli defeated him and thus secured his vow that those poor forest workers who enter the forests with empty hands and for survival needs, should be spared by him. Bonbibi although being an Islamic goddess, is widely worshipped by the Muslims and the Hindus as well as other religious communities, irrespective of caste and creed. For details see Chatterjee Sarkar (2010), Jalais (2010).

${ }^{16}$ Source: http://mustafizmamun.com/portfolio/l-a-p-d-1947
} 


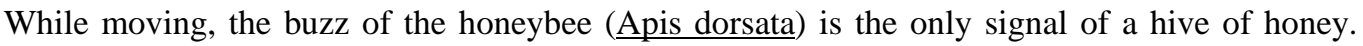
Grass and Hental leaves are lit in a fire, so that the smoke disperses the bees. When smoke emerges, the bees instinctively behave as if the forest is on fire and disperse, since they are programmed to believe the hive is doomed and there is no point protecting it. These giant Asian honey bees are aggressive, and feed on the nectar of the mangrove flowers and in the process, pollinate them. Before extracting the honey, the collectors cover their entire face apart from their eyes with a towel to prevent beestings. However attacks still occur, after the smoke is set, since the bees associate people with threats to their hive. A collector (commonly known as gachal) climbs up the tree to break the hive with the knife, while the others stand below holding the aluminium pot (aari) to collect the honey. The collectors always leave behind a considerable part of the hive, so the bees can make a new one within 14-15 days. Even after the first chunk of hive is broken, they offer the first piece as a sacrament to Bonbibi. A mature bee hive can fetch the collectors up to $20 \mathrm{~kg}$ of honey. The pot is carried back to the boat based on the direction given by the bhorel and his singhe. They collect honey the entire day, starting from seven in the morning till four in the evening. But in the afternoon, they do not enter the forest, since it is believed to be the resting time of the animals and breaching this rule would enrage Bonbibi. They stay on the creeks for the fifteen days of the permitted collection season, sleeping in the boat at night.

The Sundarban forest is particularly dangerous for humans, as we have explained, and collecting honey is one of the most dangerous occupations. Syama, who lives in a small hutment in Emilibari village beyond the embankment, explained that the deepest forest is normally the resting places of the tiger in the summer months of April and May. It is difficult for them to come out of the forests in search of prey because of the heat and they prefer to stay in a cooler place, in shades of dense trees like Hental, Garjan and Khalsi; the same trees that host the hives. As the honey collectors usually say, 'finding honey in the trees is tantamount to finding a tiger', every step has to be taken cautiously. Tigers commonly attack prey from the rear. Added to this, the dense smoke reduces visibility, making tigers harder to spot. They usually have fixed territories of their own which they can demarcate by the stench of their excreta. Thus they become very aggressive when any other creature enters the zone demarcated by them. Mawaleys recall that there are certain honeys bearing trees which the tiger visits almost every day, evident from the fresh pawprints. This is because, they say, they know people will come there and they will be easy prey.

It is well known to their families that the honey collectors might not all return. This very reason makes them reliant on Bonbibi, who is worshipped early in the morning the day the mawaleys leave for honey collection from their home. During the period of mahal, their wives refrain from putting vermillion on their foreheads till their husbands return, do not entertain guests, do not visit crematoriums, do not wash utensils and keep their door open all day, mimicking a mourning period. There have been several instances where many people have been saved miraculously from the tiger, which they believe was the gift of mother Bonbibi. This belief system of the mawaley is rooted in their long traditional association with and use of the forests. They believe that the forest and Bonbibi sustains them. This belief system is reinforced by the tiger charmers who are said to be versed in mythical hymns that drive the tigers away if they are recited in front of them. Tiger charmers are believed to inherit the hymns from mother Bonbibi and thus they usually keep them secret, except when they grow old, transmitting them to an heir. They practice certain prohibitions - not entering the forest on Fridays and refraining from eating pork and crab. They are also believed to control storms or prevent ailments along with the power to drive away evil spirits (Jalais, 2010: 76). However, forest workers should not take resources from the forests beyond their needs; offenders are believed to incur the wrath of Bonbibi and fall a victim to a tiger.

The honey collectors are the poorest sector of population residing with Sundarban. They live at the side of the river, bordering the embankment, prone to erosion and submergence at any time. Their only other occupation is fishing, they have practically no income during the lean seasons when honey collection is not permitted, lack basic education, and suffer waterborne diseases. If an 'accident ${ }^{17}$ happens in the family, there is little support. The collection of honey, for which the Forest Department is dependent upon the islanders, constitutes a threat at every moment. While the honey collectors venture the forests in search of honey, bee stings are treated as auspicious. They believe that if a honey bee attacks them, they will be spared from any disease throughout the year. In their work, it is striking that they have no defences other than resorting to supernatural beliefs. With each journey into the

\footnotetext{
${ }^{17}$ Tiger attacks and subsequent deaths are usually referred to as accidents by the people.
} 
forests, the honey collectors carry with them a set of traditional practices and rituals, and their own sense of precaution and experience. This traditional respect for the forest means they spare flowering trees which will yield honey in the future. They also spare the small bees and its eggs and cut the honey so that the eggs remain intact. The mawaleys are quite adept with identifying the best quality, thick honey.

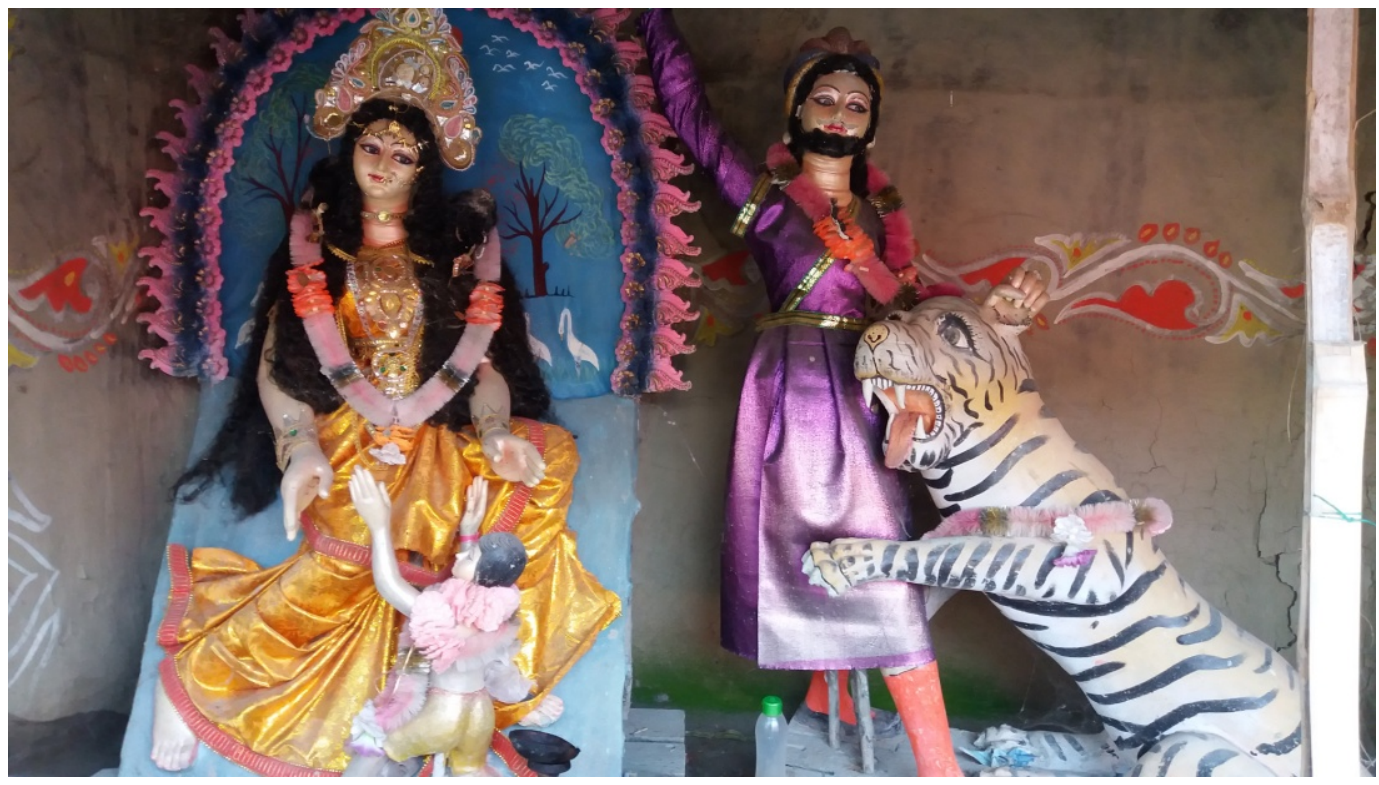

Figure 3: Bonbibi, Shah Janguli and the tiger demon Dakshin Ray. Source: photo from field visit.

The honey which the mawaleys collect braving their lives, has to be deposited at the Forest Offices at a current rate of Rs 150 (US\$2.34)/kg. Previously it was Rs 50 (US\$ 0.78) to Rs 75 (US\$1.17), which is quite nominal compared to market rates. Honey is then sold to companies like Dabur, at a rate of Rs 350- Rs 370 (US\$5.50-5.80)/kg after adding preservatives and water, according to all the honey collectors with whom we interacted. Figure 4 shows that crude honey collection was lower between 2008 and 2011, but increased substantially in the next two years.

\begin{tabular}{|c|c|c|}
\hline Year & Quantity collected (in kg) & Value earned (in INR) \\
\hline $2004-2005$ & $22,119.500$ & $11,50,215.00$ \\
\hline $2005-2006$ & $30,552.000$ & $17,26,799.00$ \\
\hline $2006-2007$ & $25,170.000$ & $13,56,176.00$ \\
\hline $2007-2008$ & $21,368.000$ & $13,03,446.00$ \\
\hline $2008-2009$ & $12,550.000$ & $7,16,479.00$ \\
\hline $2009-2010$ & $13,800.000$ & $8,78,734.00$ \\
\hline $2010-2011$ & $14,300.000$ & $10,27,425.00$ \\
\hline $2011-2012$ & $18,025.000$ & $15,59,250.00$ \\
\hline $2012-2013$ & $24,750.000$ & $15,71,250.00$ \\
\hline $2013-2014$ & $20,950.000$ & \\
\hline
\end{tabular}

Figure 4: Collection of wild honey from 2004-2014. Source: STR Annual Report 20132014. 
According to the honey collectors, an 'accident' or death brings additional harassment by the Forest Department. Establishing a death is arduous, since the forest guards accompany the companions of the deceased to locate the place of the accident, but in an atmosphere of suspicion. Thus the victim's family is often, as with fisherfolk, denied official compensation. There is a serious concern among the honey collectors about whether the forests of Sundarban can actually be conserved by functionaries of the state who, according to them know very little about the forests, its flora and fauna. PA management is frequently called into question, given distrust expressed towards local people. According to them, the forest needs to be cut and re-grown to remain healthy. The core conservation areas are not maintaining their biodiversity. Rich mangrove species like Garjan have already started to rupture and break down. Garjan, according to the locals, if cut well from below, develops at least four to five stilts. But since it is not allowed, the existing Garjan are dilapidating and no new varieties are growing. The branches of Nipa Palm (Nepa fruticans), locally known as Golpata, needs to be cut from time to time, through the brown edges of its mature branches. But the forest guards do not allow this, meaning Nipa are not thriving. Wood is losing its dexterity and is becoming fragile. People can demonstrate the greater success of trees on the inhabited islands which they cut from time to time. These have vigour, while the closed areas have bushes rather than trees. Well maintained flowering plants would be thriving sites for honey.

The defiant mode of the Forest Department towards the traditional knowledge of the forest workers reflects the apathy towards recognizing the "alternative knowledge claims from actors" who are neglected in the creation of dominant "environmental narratives" (Forsyth 2005: 168). Dominant environmental narratives refer to the repetitive patterns of environmental explanations, about how ecosystem works or how it might get degraded (ibid). There have been cases were a mawaley was able to extract 1.5 quintals (150 kg) of honey from a single hive. But the permitted period in April and May is not the ideal time for the hives to fully mature. Several fishermen's unions have asked for a two month extension, but it has not been approved by the Forest Department. There is no justification provided by the Department for taking the entire amount of honey collected.

\section{Marginalizing forest workers and defending the pristine wilderness}

Our observations suggest that the forest workers, despite being 'non indigenous', are aware of ecological limits like fish reproduction cycles and employ sustainable honey extraction techniques. Spiritual and cultural values also play an important role in understanding local ecological processes and establishing intimate links and reverence for the forest. The process of honey collection and the rituals observed are not only to treat forests as a consecrated space, but to integrate the local rules of forest usage and the principles of sustainable extraction (Sen 2016). Traditional methods involve fishing nets, tailored to different kinds of fishing. According to Ray (2013), fishing nets like Khalpata and Charpata are specially designed to be used in the river creeks, pleated and concealed during the ebb tide and lifted during the high tide. Seine nets are used in the reservoirs and rivers or ponds tied with two bamboo poles to form a large net wall. The fishing nets are not technology-intensive but stitched at home, without any destructive effects. Many of our respondents started catching fish from a very early age (five or six for many respondents) and said they were aware of the breeding season and refrained from fishing during that period. Such practices continue today. According to a study by DISHA (2009) traditional fishers knew from childhood when not to catch different species. If they entered the net, the practice was to release them. Religious customs also prohibit eating fish at certain times of the year. So, local knowledge of fishing is based on experience, with a unique belief system that also considers the forests as a source of healing. Especially the fruits of trees like Garjan, revered by the communities and believed to cure any disease.

Drawing on Berkes, Folke and Gadgil (1995:283), local and regional ecosystems are embedded within social relations as well as the beliefs and practices that form traditional knowledge. Even within localities, the communities have an intimate knowledge of natural resources, which has permitted the survival of several biological species (Gadgil and Rao 1995:57). However, the rigid demarcations of PAs, in this case the established designation of a tiger reserve, impinge directly on local livelihoods of the poor (Guha 1989:75). Statist resistance towards subsistence based livelihoods like forest fishing and honey collection are illustrated through the ways in which Forest Department acts as a reprimand to the values and ethics of the forest workers. Local knowledge as a reliable option for conservation (like periodic slitting for re-growth of certain mangrove species) has escaped their thinking. This, according to Forsyth (2005: 165), forms one contemporary focus of political ecology, centring the "political 
authority of different knowledge claims about the environment" and the construction of "authoritative knowledge." Knowledge construction is certainly power-laden in this region. International conservation groups have imposed additional pressures on the state of West Bengal to prioritize wildlife conservation in the mangrove ecosystem of Sundarban, as a World Heritage Site. The unilateral financial assistance directed by international environmental NGOs (like WWF) to conserving Sundarban forests has actually reinforced the accountability of the state forestry institutions to augment their less than effective capacity in controlling local access to resources. Following Peluso (1993: 201), it can be said that in Sundarban, "global concerns over conservation have imposed additional pressures on the state, in the hope of achieving sustainable management objectives." Figure 5, showing the results of some of these 'pressures' through enforcement, is an offence report published by the STR office for 2009-2014. Identified as a trend towards neoliberal conservation, or "a latest incarnation of capitalism" as Veron (2006: 2094) calls it, intervention by international NGOs actually promotes economic activities and commodification of natural resources (Fletcher 2010:172; see also Brockington and Duffy 2010).Socioecological relationships are juxtaposed against the influence of power and inequitable distribution of resources - seizing goods and fining local people rather than trusting their ecological management skills.

\begin{tabular}{|c|c|c|c|c|c|}
\hline & 2009-2010 & $2010-2011$ & 2011-2012 & $2012-2013$ & 2013-2014 \\
\hline $\begin{array}{l}\text { POR (Preliminary } \\
\text { Offence Report) }\end{array}$ & 11 & 16 & 6 & 6 & 1 \\
\hline $\begin{array}{l}\text { COR (Compounded } \\
\text { Offence Report) }\end{array}$ & 1684 & 1957 & 2221 & 2499 & 2577 \\
\hline $\begin{array}{l}\text { UDOR (Undetected } \\
\text { Offence Report) }\end{array}$ & 69 & 72 & 81 & 58 & \\
\hline $\begin{array}{c}\text { No of persons } \\
\text { arrested }\end{array}$ & 35 & 90 & 18 & 36 & 8 \\
\hline $\begin{array}{l}\text { Incidence of firing by } \\
\text { staff (in round) }\end{array}$ & NIL & NIL & NIL & 17 & NIL \\
\hline No of offenders died & NIL & NIL & NIL & NIL & NIL \\
\hline $\begin{array}{c}\text { No of offenders } \\
\text { injured }\end{array}$ & NIL & NIL & NIL & NIL & NIL \\
\hline $\begin{array}{c}\text { No of forest staff } \\
\text { killed }\end{array}$ & NIL & NIL & NIL & NIL & NIL \\
\hline $\begin{array}{c}\text { No of forest staff } \\
\text { injured }\end{array}$ & NIL & NIL & NIL & NIL & NIL \\
\hline $\begin{array}{l}\text { Total compensation } \\
\text { realised (in Rs) }\end{array}$ & $\begin{array}{c}8,25 \\
834,00\end{array}$ & $8,63,690.00$ & $\begin{array}{c}10,92,700 \\
00\end{array}$ & $\begin{array}{l}17,12, \\
860.00\end{array}$ & $19,65,450.00$ \\
\hline $\begin{array}{c}\text { Quantity of timber } \\
\text { seized (sawn and } \\
\text { logs) }\end{array}$ & $0.5 \mathrm{M}^{3}$ & NIL & $\begin{array}{l}225 \text { quintals } \\
\text { of fuel wood }\end{array}$ & $\begin{array}{c}35 \text { quintals } \\
\text { of fuel } \\
\text { wood }\end{array}$ & $\begin{array}{l}1,8263 \mathrm{M}^{3} \text { of } \\
\text { timber+52, } 811 \\
\mathrm{M}^{3} \text { of firewood }\end{array}$ \\
\hline No of vehicles seized & NIL & 8Cycle Vans & 1 Cycle Van & $\begin{array}{c}2 \text { Van } \\
\text { Rickshaw }\end{array}$ & NIL \\
\hline No of dinghy seized & 13 & 22 & 37 & 16 & 7 \\
\hline $\begin{array}{l}\text { No of mechanized } \\
\text { boat/trawler seized }\end{array}$ & 19 & 37 & 4 & 3 & 3 \\
\hline No of cattle seized & 91 & 218 & 52 & NIL & NIL \\
\hline
\end{tabular}

Figure 5: Forest offences and seizure from 2009-2014. Source: STR Annual Report (2013-2014).

Fishing is a major flashpoint with the authorities. A combination of factors challenges small scale fishing livelihoods in Sundarban. When the fishermen go for fishing deep inside the creeks, they 
have to carry their own food and drinking water, since they go for at least a week. They used to cook with wood, sourced from floating timber or around the mudflats. But now this is no longer an option. For the last few years, the Forest Department has ordered that each boat has a kerosene stove instead. This, according to the fishermen, is time consuming; since it is frustrating to light a stove in the midst of a forest surrounded by material for a fire. Wood costs nothing and a fire complements breaks in fishing - kerosene is expensive.

Within our sample, 22\% households fish with a BLC (Boat Licence Certificate), and the rest do not have an official permit. Due to the endless debt cycle of BLC rent to the aratdaars, bribes to the forest guards and confiscation of catches, fishermen resort to illegal fishing. But there is awareness of sustainable fishing. According to the narratives recorded in Emilibari, many fishermen have switched to crab fishing as fish stocks have declined. Many fishermen propose the development of inshore aquaculture as an alternative livelihood, less susceptible to tiger attacks. The use of otters to catch fish is one of the less obtrusive measures to catch fish. According to Sasanka Mandal of Emilibari, who was a member of a fishermen union for twelve years, a real problem is the concentration of assets away from the fishers themselves, through the permitting system:

Previously Satjelia had 22-23 BLCs (owned) which has now reduced to 3. Aratdaars have at a large scale monopolised them. This is preventing the fishermen to get the market price of the fish being caught by them and the aratdaars, acting as the middlemen, are actually getting the market price.

He had often raised the need to provide the fishermen with mechanised or motor boats so they can ply from these distant islands to markets in Canning, avoiding the aratdaars and thus receiving a fair market price.

The challenges posed by official conservation methods are several. Firstly, there is no scientific study of fish stock management within the STR. The Fisheries Department of West Bengal, CMFRI etc. are not involved in, or rather are not allowed by the Forest Department to get involved in doing a stock assessment, due to internal political reasons which were undisclosed to us. Departments, it seems, hold onto and control knowledge and power. Secondly, the Forest Department cannot say why only 650 out of the 923 BLCs are active. Thirdly, while forests guards confiscate equipment from the fishermen, no confiscation note is issued to them, questioning what happens to this fishing gear. Public pressure has begun on this point. Lastly, the question of compensation to be paid after the death of a person by a tiger attack inside the buffer area of the forest. The rule is that the family of a person who enters a forest buffer area with a permit and dies, is entitled to a cash compensation of one lakh rupees (US\$1,562) from the Forest Department (no compensation is to be provided in case of a core area). The same amount is assured from Janata insurance, the district level council ${ }^{18}$ and the Fisheries Department. However in reality, the Forest Department has very rarely paid compensation. Since most of the accidents happen inside the core area, they have reasons to support this claim. The forest guards in fact tend to write down on the permit that the accident has happened inside the core conservation area to make sure that no compensation is paid at all. The payment from the district level council requires high level political connections to procure the money. Most of the fishermen don't know about the Fisheries Department insurance, and most lack a biometric card indicating their occupation. In many cases the village council office doesn't certify them as fishermen after an accident happens. Thus, apart from the Janata insurance, families hardly receive any compensation.

Another annoyance is than the crab fishing season, permitted from June to March, is almost always delayed by a month, starting in July, due to delays in administrative procedures. This loses a month's income for the fishermen. Added to this, if by mistake on entering a core area, their pass is ended by a forest guard, and it takes another two weeks to release it, which means they miss an entire lunar cycle (gon) - further reducing their income.

Many NGOs, like Direct Initiative for Social and Health Action (DISHA), have time and again pointed out that the entire system of issuing BLC is flawed. If the Forest Department could issue passes to at least $90 \%$ of the fishermen (those who are regularly visiting forests in the last five years) every

\footnotetext{
${ }^{18}$ In the three-tier Panchaytai Raj (local self governance) system administering villages in India, the district councils form the highest level, situated at the individual districts. District councils are followed by block level councils in individual blocks. Village councils are formed in individual villages, referred to as gram panchayats.
} 
fishing season and the rest (10\%) be made to apply for passes, then the licensing problem would be solved. But here there is an inequality in access. The patrons of political parties will tend to acquire licenses faster than others, requiring monitoring. According to our interview with Anamitra Anurag Danda, head of the Indian Sundarbans Programme of WWF, the allocation of the BLCs needs a rationalization since they were issued at a time prior to 1980s and nobody recollects the reasons used back then.

Lastly, in Satjelia, fishermen have themselves caught pirates felling wood within the forests, but there has been no official response to cease this. According to the forest workers, illegal felling happens after the payment of bribes to the Forest Department, and this has become so endemic that people have stopped questioning it.

\section{Discussion and conclusions}

To enrich its scholarly contributions, the field of political ecology needs to incorporate alternative socio-ecological relations within what Walker (2007: 367) refers to as its "core philosophical concern for social and environmental justice." Being migrants and without any 'authentic' or prior forest rights, the Forest Department has denied local livelihood claims in Sundarban. Making universal claims about the impact of indigenous knowledge on local ecosystems, excludes questions of cultural diversity within political ecology debates. Indigenous people, like India's tribals, are usually typified by their geographical isolation in hilly or forested regions, along with a degree of ethnic closure, holding them distinct from other communities (Corbridge 1998:6). Their ecosystem knowledge is rooted in their cultural heritage. Cultural identity thus forms a part of their claim-making (Karthik and Menon 2016: 48). Li (2000: 151, 174) explains how certain communities "articulate" an indigenous identity through particular forms of political struggle, to ground their livelihoods in particular places and contest the arbitrary state power to exploit. However the complex of beliefs and practices that influence ecological processes necessitates going beyond struggle alone, to consider broader symbolic representations and knowledge systems (Lanzano 2013: 5, 6).

The empirical observations in this study reveal how 'non-indigenous' life-worlds also articulate distinct ecological knowledge and frame the practices of sustainable livelihoods through cultural and ritualistic practices. Unlike indigenous ecological knowledge, the knowledge of the 'other' forestdependent communities in Sundarban is learnt through experience, and growing associations with forests based on needs. Knowledge cannot be the property [emphasis added] of a specific group over a period of time and cannot be characterised in a particular way (Agrawal 1995: 423). The "indigenistnativist environmental discourse" shaping dominant environmental thinking misrecognizes the ecological knowledge that other communities might possess (Chhotray 2016). We argue that cultural rights and identities are equally important within non- indigenous communities. Conflicts over access that fisherfolk and honey collectors face are particularly relevant in the context of "third world political ecology": an agenda, well represented in this Journal, which attempts an integration of environmental and political analysis to better understand human destiny in developing countries (Bryant 1992: 28).

The mythology of Bonbibi supports only subsistence claims, and not overuse or resources. The tiger charmers, who are believed to be responsible for striking a balance between human and nonhuman needs, set a proper time to enter the forest without disturbing the animals and ensure other group members respect the "rules" of the forest by keeping it clean and not procuring more than what they need (Jalais 2010: 84). Sundarban is the only context where a deity is worshipped not only as a prerequisite of a custom, but because of need, the need to seek the cooperation of nature before entering the forest. It is precisely because of this collective pursuit of protection, that Bonbibi, despite origins as a Muslim deity, transcends communal barriers and is worshipped by all the forest workers irrespective of caste and creed. Local fishing and honey collection practices conform to forest conservation principles and indeed have ingrained rituals and practices which revere the forest as sacred. However, such reverence is ignored by the state in its control of the PA as well as in its practiced demarcation between 'indigenous' and 'other' local knowledge. The regional criteria of indigenous knowledge might claim cultural resonance in terms of autonomy, presence of ancestral lands, ethnicity and political expression. But there is little recognition of the relatively young cultural history of the forestdependents, which has equal specificities in terms of addressing environmental thinking. Local traditional knowledge of the 'non indigenous' forest-dependent communities is undervalued, in spite of its pertinence to local conditions and a definite conservation agenda. 
The Forest Department has forged an authoritarian path of coercive conservation, straining the relationship between the forests and the people. According to Robbins (2012), modernist developments designed to improve production systems have in fact led to a decrease in sustainability with a linked decrease in the equity of resource distribution for local people. Locally, this is manifested as a high targets for local honey collection (75 MT for 2015-2016, against 34 MT previously), all of which is sequestered from the collectors by the Department, and some proscribed forest cutting and clearing. By denying insurance payouts to the family of deceased hunters and fishers, and physical and verbal abuse directed at those traveling through the core areas by boat, the state instantiates the "use of violence to exercise control, appropriating the language of conservation to legitimate both its claims and enforcement methods" (Peluso 1993:201). The Forest Department denies the authenticity of the claims made by local communities to be conservationists themselves. Quite interestingly, Jalais (2004: 161) notes that since most of the Forest Department staff do not hail from Sundarban, Bonbibi is bypassed as an element of "superstition" by the forest workers used to comfort them in the face of potentially fatal tiger attacks. The department functionaries are more inclined to worship 'mainstream goddesses' like Kali and Tara, which are well inscribed within the Hindu pantheon (ibid).

There are a few techniques which might help to achieve the imperatives of conservation without endangering local livelihoods. If the Forest Department divided the fishing boats according to odd numbers and even numbers and kept a record of the number of boats entering the forests, permitting each group to enter in a particular lunar cycle, then restrictions on core and buffer areas could be eased. A particular section of the forest could open for a particular period of time irrespective of its PA status, while the rest could be closed off and allowed to grow. This process could be more dynamic than the present one by rotating the resource extraction zones. Management of the Reserve's timber is an urgent need. Distribution of dry fuelwood through Joint Forest Management Committees (JFMCs) also makes ecological and social sense. Although JFMCs exist in the area, elite capture and bureaucratic interventions currently dominate them. Customary practices are deemed to be small-scale and marginal (Sen and Pattanaik 2017). In sum, a recognition of non-indigenous community rights is particularly important - or an extension of indigenous rights to the groups described in this article. We suggest that sensitivity towards the livelihood of the 'non-indigenous' communities, and integration of their livelihood practices with recognized indigenous groups, might lead to viable-capacity building measures within the management of protected areas in the Sundarbans.

\section{References}

Adams, W.M. and J. Hutton. 2007. People, parks and poverty: political ecology and biodiversity conservation. Conservation and Society 5(2): 147- 183.

Agrawal, A. 1995.Dismantling the divide between indigenous and scientific knowledge. Development and Change 26(3): 413-439.

Alfred, G.R. and F. Wilmer. 1997. Indigenous peoples, state, conflict. In Carment, D. and P. James (eds.) Wars in the midst of peace. Pittsburgh: University of Pittsburgh Press. Pp. 26-44.

Baviskar, A. 1995. In the belly of the river: tribal conflicts over development in the Narmada valley. New Delhi: Oxford University Press.

Baviskar, A. 1997.Tribal politics and discourses of environmentalism. Contributions to Indian Sociology 31(2): 195-223.

Baviskar, A. 2000.Claims to knowledge, claims to control: environmental conflict in the Great Himalayan National Park, India. In Roy, E., P. Parkes and A. Bicker (eds.)Indigenous environmental knowledge and its transformations: critical anthropological perspectives. Amsterdam:Harwood Academic Press. Pp. 101-119.

Berkes, F., C.Folke and M. Gadgil. 1995. Traditional ecological knowledge: biodiversity, resilience and sustainability. In Perrings, C.A., K.-G. Mäler, C. Folke, C.S. Holling and B.O. Jansson (eds.) Biodiversity conservation. Dordrecht: Kluwer. Pp. 281-299.

Béteille, A. 1998.The idea of indigenous people. Current Anthropology 39(2): 187-192. Scribd

Brockington, D. and R. Duffy. 2010. Capitalism and conservation: the production and reproduction of biodiversity conservation. Antipode 42(3): 469-484. Researchgate

Bryant, R.L. 1998. Power, knowledge and political ecology in the third world: a review. Progress in Physical Geography 22(1): 79-94. Scribd 
Bryant, R.L. 1992. Political ecology: an emerging research agenda in third world studies. Political Geography 11(1): 12-36.

Capistrano, D. 2010. Indigenous people, their livelihoods and fishery rights in Canada and the Philippines: paradoxes, perspectives and the lessons learnt. New York: United Nations Division for Ocean Affairs and the Law of the Sea Office of Legal Affairs.

Chakrabarti, R. 2009. Prioritizing the tiger: a history of human tiger conflicts in the Sundarban. Current Conservation 4(4): 44-47.

Chacraverti, S. 2014. The Sundarbans fishers: coping in an overly stressed mangrove estuary. Chennai: International Collective in Support of Fishworkers (ICSF).

Chatterjee Sarkar, S. 2010. The Sundarbans: folk deities, monsters and mortals. New Delhi: Orient Black Swan.

Chhotray, V. 2016. Justice at sea: fisher's politics and marine conservation in coastal Odisha, India. Maritime Studies 15(4): 1-24.

Corbridge, S. 1988. The ideology of tribal economy and society: politics in the Jharkhand, 1950-1980. Modern Asian Studies 22(1): 1-42.

Corntassel, J.J. 2003. Who is indigenous? 'peoplehood' and ethnonationalist approaches to rearticulating indigenous identity. Nationalism and Ethnic Politics 9(1): 75-100.

Cronon, W. 1995.The trouble with wilderness. In Cronon, W. (ed.) Uncommon ground: rethinking the human place in nature. New York: W.W. Norton and Co. Pp. 69-90.

CMFRI (Central Marine Fisheries Research Institute, Kochi). 2010. Marine fisheries census, 2010. Ministry of Agriculture, New Delhi and CMFRI, Kochi.

DISHA. 2009. Traditional fishers in the Sundarban Tiger Reserve: a study on livelihood practice under protected area. Kolkata: Direct Initiative for Social and Health Action.

Dudgeon, R.C. and F. Berkes. 2003. Local understandings of the land: traditional ecological knowledge and indigenous knowledge. In Selin, H. (ed.) Nature across cultures: view of the nature and the environment in non Western cultures. Dordrecht: Kluwer. Pp.79-96.

Eaton, R.M. 1990. Human settlement and colonization in the Sundarbans: 1200-1750. Agriculture and Human Values 7(2): 6-16.

Escobar, A. 1998.Whose knowledge, whose nature? Biodiversity, conservation and the political ecology of social movements. Journal of Political Ecology 5: 53-82.

Fletcher, R. 2010. Neoliberal environmentality: towards a post-structuralist political ecology of the conservationist debate. Conservation and Society 8(3): 171-181.

Forsyth, T.J. 2003.Critical political ecology: the politics of environmental science. London: Routledge.

Forsyth, T.J. 2005.The political ecology of the ecosystem approach for forests. In J. Sayer and S. Magginis (eds.) Forests in landscapes: ecosystem approaches to sustainability. London: Earthscan. Pp. 165-176.

Forsyth, T.J. 2008.Political ecology and the epistemology of social justice. Geoforum 39(2): 1-17.

Gadgil, M. and P.R.S. Rao. 1995. Designing incentives to conserve India's biodiversity. In S. Hanna and M. Munasinghe (eds.). Property rights in a social and ecological context. Washington D.C. The Beijer International Institute of Ecological Economics and the World Bank. Pp. 53-62.

Gadgil, M.,F. Berkes and C. Folke. 1993. Indigenous knowledge for biodiversity conservation. Ambio 22(2/3): 151-156.

Gadgil, M and R. Guha. 1992. This fissured land: an ecological history of India. New Delhi: Oxford University Press.

Gadgil, M. and R. Guha. 1995. Ecology and equity: use and abuse of nature in contemporary India. New Delhi: Penguin.

Ghosh, P. 2014. Subsistence and biodiversity conservation in the Sundarban Biosphere Reserve, West Bengal, India. Ph.D. dissertation. Lexington: University of Kentucky.

Greenough, P. 2001. Naturae Ferae: wild animals in South Asia and the standard environmental narrative. In Scott, J. and N. Bhatt (eds.) Agrarian studies: synthetic work at the cutting edge. New Delhi: Oxford University Press. Pp. 141-185.

Gupta, A. 1998.Postcolonial developments: agriculture in the making of modern India. Durham: Duke University Press. 
Guha, R. 1989. Radical American environmentalism and wilderness preservation: a third world critique. Environmental Ethics 11: 71-83.

Guha, R. and J.Martinez-Alier. 1997. Varieties of environmentalism: essays North and South. London: Earthscan.

Gurr, T.R. 2000.Peoples versus states: minorities at risk in the new century. Washington D.C.: United States Institute of Peace Press.

Harris, R.H. 2010. Rangeland degradation on the Qinghai-Tibetan plateau: a review of the evidence of its magnitude and causes. Journal of Arid Environments 74(1): 1-12.

Harrison, E. and A. Mdee. 2017. Successful small scale irrigation or environmental destruction? The political ecology of competing claims on water in the Uluguru Mountains, Tanzania. Journal of Political Ecology 24: 406-424.

Hunter, W.W. 1875. A statistical account of Bengal: district of the 24 Parganas and Sundarbans. London: Trubner \& Co.

Jalais, A. 2004. People and tigers: an anthropological study of the Sundarbans of West Bengal, India. PhD dissertation. London: London School of Economics and Political Science.

Jalais, A. 2010. Forest of tigers: people, politics and environment in the Sundarbans. New Delhi: Routledge.

Karthik, M. and A. Menon. 2016. Blurred boundaries: identity and rights in the forested landscapes of Gudalur, Tamil Nadu. Economic and Political Weekly LI (10): 43-50.

Kull, C.A., X.A. de Sartre and M.C. Larranaga. 2015. The political ecology of ecosystem services. Geoforum 61: 122-134.

Lanzano, C. 2013. What kind of knowledge is 'indigenous knowledge'? Critical insights from a case study in Burkina Faso. Transcience 4(2): 3-18.

Li, T.M. 2000. Articulating indigenous identity in Indonesia: resource politics and the tribal slot.Comparative Studies in Society and History 42(1): 149-179.

Mukhopadhyay, A. 2016.Living with disasters: communities and development in the Indian Sundarbans. New Delhi: Cambridge University Press.

Peluso, N.L. 1993. Coercing conservation? The politics of state resource control. Global Environmental Change 3(2): 199-218. Academia

Ray, T. 2013. Indigenous fishing knowledge of Sundarban. Lokaratna V \& VI: 1-11.

Robbins, P. 2012. Political ecology: a critical introduction. Oxford: Blackwell.

Sen, A. 2016. Honey, they shrunk our livelihoods! Down to Earth. $31^{\text {st }}$ December 2016. Available at http://www.downtoearth.org.in/news/honey-they-shrunk-our-livelihoods--56630

Sen, A. and S. Pattanaik. 2015. Alienation, conflict and conservation in the protected areas of urban metropolis: a case study of Sanjay Gandhi National Park, Mumbai. Sociological Bulletin 64(3): 375-395.

Sen, A. and S. Pattanaik. 2017. Role of CBNRM in the livelihoods of Sundarban: implications of customary rights, law and practices. Economic and Political Weekly LII (29): 93-104.

Shahabuddin, G. and M. Rangarajan (eds.). 2007. Making conservation work. Uttaranchal: Permanent Black.

Veron, R. 2006. Remaking urban environments: the political ecology of air pollution in Delhi. Environment and Planning A 38(11): 2093-2109.

Walker, P.A. 2007. Political ecology: where is the politics? Progress in Human Geography 31 (3): 363369.

Wilmer, F. 1993. The indigenous voice in world politics. Newbury Park, CA: Sage. 